\title{
Mathematical Model for Alternative Fuel Combustion in a Rotary Cement Kiln Burner
}

\author{
W. K. Hiromi Ariyaratne, E. V. P. J. Manjula, Morten C. Melaaen, and Lars-André Tokheim
}

\begin{abstract}
Increased use of alternative fuels in cement kilns is a trend in the world. However, replacing fossil fuels like coal with different alternative fuels will give various impacts on the overall kiln process due to the inherent fuel characteristics. Hence, it is important to know to what extent the fossil fuels can be replaced by different alternative fuels without severely changing process conditions, product quality or emissions. In the present study, a mathematical model based on a mass and energy balance for the combustion of different alternative fuels in a cement rotary kiln was developed. First, the impact of different fuel characteristics on kiln gas temperature, kiln gas flow rate and air requirement were observed by using coal (reference case), meat and bone meal (MBM), two different wood types, refuse derived fuel (RDF) and a mixture of saw dust and solid hazardous waste as the primary fuel. It was found that the key process parameters depend largely on the chemical characteristics of the fuel. It appears that MBM shows quite different results from other alternative fuels investigated. Next, simulation of combustion of a mixture of coal and MBM in the rotary kiln burner was carried out in three steps in order to find the reduction in production capacity compared to the reference case. Around $9 \%$ of reduction in clinker production rate could be observed when replacing $59 \%$ of the coal energy input. Results from a full-scale test using the same mixture of coal and MBM verified the simulation results.
\end{abstract}

Index Terms-Air requirement, alternative fuels, production capacity, rotary cement kiln burner.

\section{INTRODUCTION}

Cement kilns represent a very energy intensive sector, requiring energy inputs ranging from 3.2 to $5 \mathrm{MJ} / \mathrm{kg}$ of clinker depending on the process conditions [1]. Not only to reduce energy costs but also for saving natural resources, decreasing emissions, decreasing the need for waste disposal options and specially for decreasing the $\mathrm{CO}_{2}$ footprint of emissions, the cement manufacturers around the world are adopting the practice of using alternative fuels to replace fossil fuels in cement manufacturing.

Before any alternative fuel is put into use in cement kilns, capacity, emissions and overall operation of the process should be investigated. Finding bottlenecks will clear the path for optimizing the process and the alternative fuel consumption.

The range of alternative fuels is very wide. Some its characteristics and impacts on product quality, production

researchers have focused on emissions and pollution due to alternative fuel combustion in cement kilns [2]-[4]. Impacts in the product and the process have also been investigated by some authors. One study was carried out to investigate air demand and energy input by partly replacing primary fuel by meat and bone meal (MBM) and sewage sludge using Aspen Plus modeling tool [5]. The same authors investigated the change in clinker composition due to change of fuels [6]. A detailed mathematical model for optimal selection of raw materials and fuels has been developed by other researchers [7]. In another study, the flow of exhaust gases and the effect on operational parameters were found [8]. Furthermore, the effect of MBM ash addition on the clinkering process, a review of energy volarisation of MBM as well as environmental impacts of using MBM in cement kilns have been investigated [9]-[11].

In the present study, a mathematical model was implemented in Matlab, based on a mass and energy balance of a rotary cement kiln. There were two main objectives: 1) Investigation of the impact of different fuel characteristics on kiln gas temperature, kiln gas flow rate and air requirement using different alternative fuels as the primary fuel. 2) Quantification of the reduction of production capacity due to replacement of more than half of the primary coal energy by MBM using an expanded model, which also included the precalciner (required for the total mass balance of the system). The simulation results were verified by results from a full-scale test partly documented before [12]. A description of the kiln system is described in a previous publication [13].

\section{FUELS}

Analyses of different fuels are shown in Table I. Unit of lower heating value (LHV) is $\mathrm{MJ} / \mathrm{kg}$ whereas the rest are in $\mathrm{kg} / \mathrm{kg}$.

MBM is prepared by post-treating (grinding and sterilizing) the waste materials associated with slaughtering operations. Wood and waste wood samples are collected from Norway and China respectively. Refuse derived fuel (RDF) is derived from municipal and industrial waste which has paper, plastic and biomass as main constituents. SHW is a mixture of solid hazardous waste and saw dust. Among those fuels, only coal is fully-fossil; MBM, wood and waste wood are fully biogenic; whereas RDF and SHW are partly biogenic [14].

\section{METHOD}

The authors are with Telemark University College, Department of Process, Energy \& Environmental Technology, Faculty of Technology, Kjølnes Ring 56, Post box 203, N-3901 Porsgrunn, Norway (e-mail: hiromi.ariyaratne@hit.no, morten.c.melaaen@hit.no, Lars.A.Tokheim@hit.no). edirisinghe.m@gmail.com, 
clinker per day. Only the rotary kiln burner was included in the model, however a mass balance for the precalciner was also carried out in order to determine the total exhaust gas flow rate at normal conditions. This figure is required to determine the reduction in clinker production rate when alternative fuels are used in the rotary kiln burner. Mass and energy transfer streams in the rotary kiln are shown in Fig. 1.

TABLE I: ULTIMATE ANALYSIS OF DIFFERENT FUELS (AS RECEIVED)

\begin{tabular}{lllllll}
\hline \hline \multirow{2}{*}{ Parameter } & Coal & MBM & Wood & $\begin{array}{l}\text { Waste } \\
\text { wood }\end{array}$ & RDF & SHW \\
\hline LHV & 28.3 & 18.5 & 17.0 & 14.9 & 18.2 & 15.9 \\
C & 0.729 & 0.471 & 0.448 & 0.403 & 0.431 & 0.359 \\
H & 0.039 & 0.069 & 0.058 & 0.053 & 0.062 & 0.053 \\
O & 0.056 & 0.045 & 0.408 & 0.390 & 0.304 & 0.285 \\
S & 0.014 & 0.005 & 0.002 & 0.000 & 0.004 & 0.012 \\
$\mathrm{~N}$ & 0.017 & 0.097 & 0.001 & 0.041 & 0.007 & 0.006 \\
Ash & 0.136 & 0.272 & 0.006 & 0.071 & 0.121 & 0.167 \\
Moisture & 1.000 & 0.040 & 0.077 & 0.042 & 0.071 & 0.118 \\
\hline \hline
\end{tabular}

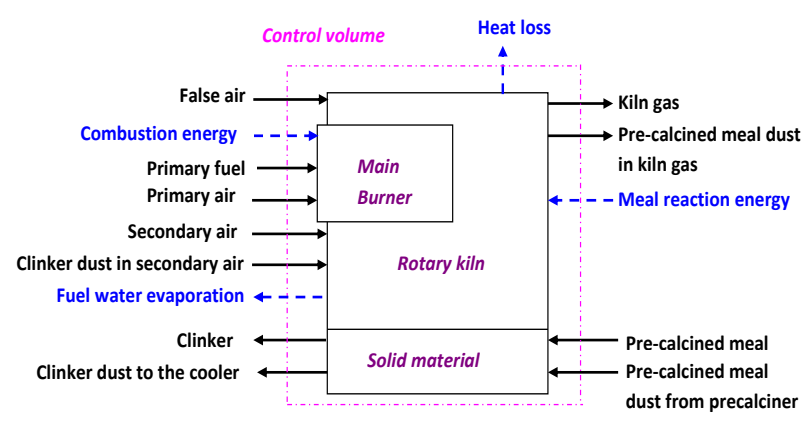

Fig. 1. Conceptual model of the rotary kiln (solid lines: mass streams and sensible energy flows; dotted lines: other energy streams).

\section{A. Combustion of Pure Fuels (Case 1)}

In case 1 , the simulations were carried out for six different pure fuels in the rotary kiln burner, one with coal, which is considered the reference case, and then the coal was totally replaced with the different alternative fuels described above.

\section{B. Combustion of a Mix of Coal and MBM (Case 2)}

In the first step of case 2, a mix of MBM and coal was supplied to the rotary kiln burner. The mass flow rate of MBM was kept at $7 \mathrm{t} / \mathrm{h}$ (the maximum capacity found in the full-scale test [12]), and the coal flow rate was calculated to give the same total fuel energy input as in the coal reference case. In the second step, the energy input to the rotary kiln burner was increased by increasing the coal flow rate of the mixture in order to obtain the same kiln gas temperature as in the coal reference case. Keeping the high temperature is crucial for maintaining the clinker mineral formation rate in the rotary kiln and hence maintaining the product quality. Increasing the fuel input however means that the clinker-specific fuel energy requirement in the rotary kiln burner was increased. The third step was to tune the coal mass flow rate and clinker production rate in order to have not only kiln gas temperature similar but also the volumetric flow rate of total exhaust gas from the precalciner similar to that of the coal reference case. This was done in order to find the reduction in production capacity due to the replacement of part of coal by MBM. The reason for keeping the total exhaust gas flow rate at the reference case level is that the major gas flow resistance is in the preheater and precalciner, and this resistance typically represents a bottleneck for the production capacity. The excess $\mathrm{O}_{2}$ for the combustion in the calciner was kept similar to the value used in the rotary kiln. The clinker-specific energy supply to the precalciner was kept constant in both cases; $90 \%$ of that energy was provided via $\mathrm{RDF}$ and the rest through coal (similar to the operation of the cement kiln system considered in this work).

\section{MODEL}

\section{A. Model Description}

Steady state was assumed for all variables in the system. Since the solid flow is fairly constant during normal operation of the kiln and the residence time for gas flow is in the order of seconds, this assumption is fairly justified. The model has five solid reactions inside the rotary kiln, including (rest) calcination, endothermic melting and exothermic sintering. $100 \% \beta-\mathrm{C}_{2} \mathrm{~S}$ formation in the rotary kiln was assumed. $\mathrm{MgCO}_{3}$ of raw meal was set to zero as $\mathrm{MgO}$ in this case is bound in other minerals than carbonates.

The secondary fuel ash is transferred to the meal in the calciner while primary fuel ash is transferred to the meal in the kiln, i.e. both ashes ending up in the clinker. The false air in-leakage in the rotary kiln was calculated as a function of secondary air flow. Dust which basically contains precalcined meal is entrained by the kiln gas and transferred to the precalcined meal in the precalciner, which means there is an energy transfer from the rotary kiln to the precalciner. Likewise, dust which basically contains clinker is entrained by the secondary air in the cooler and returned to the rotary kiln, constituting an energy transfer from the kiln to the cooler. The rate of the combustion reactions were assumed to be fast compared to the residence time in the rotary kiln, hence the chemical kinetics were disregarded. Complete combustion of primary and secondary fuels was assumed. The elemental analysis was used for the evaluation of combustion reactions. A global mechanism was assumed for all elements, and the reactions were considered irreversible. The combustion products were hence taken as $\mathrm{CO}_{2}, \mathrm{H}_{2} \mathrm{O}, \mathrm{SO}_{2}, \mathrm{~N}_{2}$ and $\mathrm{O}_{2}$. Moisture and ash were regarded as inert components. The total air supply through the rotary kiln burner inlets was kept constant independent of fuel type and fuel flow rate. The overall heat transfer coefficient for the evaluation of heat loss through rotary kiln surface was kept constant in all cases due to lack of more accurate data. Work done by kiln rotation (very small compared to the thermal energy input) was ignored in the energy balance. The specific heat capacities of the kiln gas components were calculated as temperature functions [15].

\section{B. Model Development}

The equations for the overall energy balance of the rotary kiln, the overall mass balance of the rotary kiln and the precalciner combined, as well as other relevant equations, were developed. Not all equations are presented in the paper, but a description of the model development is given below. 


\section{1) Combustion of pure fuels (case 1)}

The fuel flow rate to the rotary kiln burner was calculated based on a constant clinker-specific fuel energy consumption in the rotary kiln burner and heating values of fuels (Table I). The flow rates of different elements were found by using ultimate analysis of fuels (Table I). Then the air requirement for the combustion could be obtained; the excess air factor was specified to give 3.5 vol\% of $\mathrm{O}_{2}$ in kiln exhaust gas. This air is supplied as primary air (approximately 7-10 wt\% of the total air supply), secondary air (ca 81-83 wt\%) and false air (ca 9-10 wt\%). Next, molar flow rates of combustion products were found balancing elements. As the clinker production rate was specified and the primary and secondary fuel ash contents were known (the ash ends up in clinker), the raw meal requirement could be obtained by additionally considering $\mathrm{CO}_{2}$ release due to the decarbonation (calcination) of the calcium carbonate in the raw meal. The mass flow rate of the precalcined meal going to the rotary kiln includes the secondary fuel ash, some uncalcined calcium carbonate and calcium oxide, compounds other than calcium carbonate in raw meal and some recycled (fully calcined) dust. The recycling means that the real degree of calcination in the calciner is somewhat lower than the apparent degree of calcination. Summing the $\mathrm{CO}_{2}$ release due to rest calcination inside rotary kiln and flow of gaseous products due to combustion and fuel water evaporation, the total kiln gas flow rates and the kiln exhaust gas composition can be obtained.

To find the net enthalpy of solid reactions, equations specified by the German Association of Cement Works (VDZ) were used [15]. Equation (1) and (3) correspond to heat absorption rate for $\mathrm{CaCO}_{3}$ dissociation and $\mathrm{C}_{3} \mathrm{~A}$ formation. Likewise, (2), (4) and (5) correspond to heat release rate due to $\mathrm{C}_{4} \mathrm{AF}, \beta-\mathrm{C}_{2} \mathrm{~S}$ and $\mathrm{C}_{3} \mathrm{~S}$ formation, respectively. Then the net heat absorption rate due to solid reactions in the kiln could be calculated. To find the $\mathrm{C}_{3} \mathrm{~S}$ content of clinker, Bogue equations were used [15].

$$
\begin{aligned}
& \Delta h_{\mathrm{CaCO}_{3}}=r \dot{m}_{r m} w_{\mathrm{CaCO}_{3}, r m}\left(1-\eta_{c a l}\right) \\
& \Delta h_{\mathrm{C}_{4} \mathrm{AF}}=3.043 \mathrm{~s} \dot{m}_{\mathrm{cl}} w_{\mathrm{Fe}_{2} \mathrm{O}_{3}, \mathrm{cl}} \\
& \Delta h_{C_{3} \mathrm{~A}}=t \dot{m}_{c l}\left(2.65 w_{\mathrm{Al}_{2} \mathrm{O}_{3}, c l}-1.692 w_{\mathrm{Fe}_{2} \mathrm{O}_{3}, c l}\right) \\
& \Delta h_{\beta-C_{2} S}=u \dot{m}_{c l}\left(2.868 w_{S i O_{2}, c l}-0.754 w_{C_{3} S, c l}\right) \\
& \Delta h_{C_{3} S}=z \dot{m}_{c l} w_{C_{3} S, c l} \\
& h_{R}=\Delta h_{\mathrm{CaCO}_{3}}-\Delta h_{C_{4} A F}+\Delta h_{C_{3} \mathrm{~A}}-\Delta h_{\beta-C_{2} S}-\Delta h_{C_{3} S}
\end{aligned}
$$

Here, $\dot{m}_{m}$ is the mass flow rate of component $m(\mathrm{~kg} / \mathrm{s})$, $\eta_{c a l}$ is the real degree of calcination and $w_{m, q}$ is the weight fraction of component $\mathrm{m}$ in stream q. Subscripts "rm" and "cl" stands for raw meal and clinker, respectively. The other constants are specific heat release values of different reactions, and these are defined in the section "Model Inputs".

The overall energy balance is not presented here. However, in Fig. 1, all sensible energy flows along with mass streams and other energy streams are clearly shown.

\section{2) Combustion of a mix of coal and MBM (case 2)}

In step 1 , by keeping the MBM feed rate at $7 \mathrm{t} / \mathrm{h}$, the flow rate of coal was calculated in order to have the same energy input in the rotary kiln burner as in the reference case. Then the mass-weighted averages were taken as mixture characteristics and the same procedure was followed as in case 1 .

In step 2, instead of keeping the rotary kiln burner energy input constant, the coal feed rate was changed until the kiln temperature was as high as in the reference case.

In the third step, the clinker production rate and coal feed rate were tuned in order to keep the kiln gas temperature and the volumetric flow rate of the total exhaust gas from the precalciner similar to the reference case. For this step, the mass balance of the precalciner had to be included in the model in order to find the exhaust gas flow from the precalciner. Since the secondary (i.e. precalciner) fuel energy proportion was known (RDF:coal = 9:1), and the clinker-specific energy consumption was specified, the secondary fuel feed rate could be calculated. Then, using mass-weighted averages for the mixture parameters, the mass balance for the fuel combustion of the precalciner was carried out as for the rotary kiln burner. The $\mathrm{CO}_{2}$ release due to calcination inside the precalciner and the fuel moisture evaporation were also accounted for when finding the exhaust gas flow rate from the precalciner. By summing the exhaust gas flow rates from the rotary kiln burner and from the precalciner, the total gas flow rate out of the precalciner was found.

\section{Model Inputs}

Main model inputs are briefly described here. The clinker-specific heat consumption was set to $3.5 \mathrm{MJ} / \mathrm{kg}$ in case 1 , but was changed in case 2 , as described above. The apparent degree of calcination was kept at $88 \%$ in all cases; this is roughly corresponding to $46 \%$ of the total energy being supplied in the main burner, however slightly higher in case 2 . The raw meal composition was taken as $66 \mathrm{wt} \% \mathrm{CaO}, 21 \mathrm{wt} \%$ $\mathrm{SiO}_{2}, 5 \mathrm{wt} \% \mathrm{Al}_{2} \mathrm{O}_{3}, 3 \mathrm{wt} \% \mathrm{Fe}_{2} \mathrm{O}_{3}$ and $5 \mathrm{wt} \%$ other compounds in clinker which corresponds to $78 \mathrm{wt} \% \mathrm{CaCO}_{3}$ in raw meal [16]. The temperature of fuel and primary air, secondary air, false air, clinker and precalcined meal at the kiln inlet were 50, $750,25,1400$ and $830{ }^{\circ} \mathrm{C}$, respectively. The $\mathrm{O}_{2}$ level in the kiln gas and in the precalciner gas were kept at $3.5 \mathrm{vol} \%$ in all cases. The clinker-specific precalcined meal dust flow rate was set to 0.3 , and the clinker-specific clinker dust flow rate was set to 0.2 . The false air percentage was specified as 12 $\mathrm{wt} \%$ of secondary air, and the overall heat transfer coefficient was taken as $6.6 \mathrm{WK}^{-1} \mathrm{~m}^{-2}$, based on actual measurements in the kiln system. Temperature functions were used to calculate specific heat capacities of dry coal, air, clinker, combustion products and precalcined meal, and the others were assumed constant [15]. The constants $r, s, t, u$ and $z$ in (1) to (5) are $1778 \mathrm{~kJ} / \mathrm{kg} \mathrm{CaCO}_{3}$ in raw meal, $67 \mathrm{~kJ} / \mathrm{kg} \mathrm{C}_{4} \mathrm{AF}$ in clinker, 74 $\mathrm{kJ} / \mathrm{kg} \mathrm{C}{ }_{3} \mathrm{~A}$ in clinker, $700 \mathrm{~kJ} / \mathrm{kg} \mathrm{C} \mathrm{C}_{2} \mathrm{~S}$ in clinker, and $495 \mathrm{~kJ} / \mathrm{kg}$ $\mathrm{C}_{3} \mathrm{~S}$ in clinker, respectively [15]. 


\section{RESUlTS AND DISCUSSION}

Below, selected simulation results are plotted and discussed along with full scale test results

\section{A. Combustion of Pure Fuels (Case 1)}

Basically the impact of different fuel characteristics on selected key process parameters are discussed here.



Fig. 2. Clinker specific fuel consumption and kiln gas temperature for pure fuel combustion.



Fig. 3. Clinker specific flow rates of air and kiln gas for pure fuel combustion.

Demanding that the fuel energy input to the rotary kiln burner is the same as in the reference case, the fuel flow rates of alternative fuels are increased, mainly reflecting the heating value of the fuels (Fig. 2). The mass flow rate of waste wood is highest since it has the lowest heating value (Table I). Furthermore, differences in ultimate analysis, for example ash content, in different fuels will also give some impact on the clinker-specific fuel requirement. Given that the heating values are the same, the fuels with high ash content have higher clinker-specific fuel mass flow requirement. The reason is that the ash from the fuel, which is transferred to the clinker, has to be heated from ambient temperature up to the clinker temperature, whereas the precalcined meal only has to be heated from the calcination temperature.

In Fig. 2 and Table I, it can be seen that the kiln gas temperature also clearly reflects the fuel heating values; the higher the heating value, the higher the kiln gas temperature, but not for MBM. It is because; the kiln gas temperature is also impacted by the ultimate analysis of the fuel. An increase in molar $\mathrm{H} / \mathrm{C}$ ratio means a decrease in air requirement, which results in a higher kiln gas temperature. For example, coal and MBM have $\mathrm{H} / \mathrm{C}$ ratios of 0.64 and 1.76 , respectively, meaning that the air requirement in mass basis is higher for coal $\left(9.0 \mathrm{Nm}^{3} / \mathrm{kg}\right)$ than for MBM $\left(7.2 \mathrm{Nm}^{3} / \mathrm{kg}\right)$. However, this effect is inverted in energy basis $\left(0.32 \mathrm{Nm}^{3} / \mathrm{MJ}\right.$ for coal vs
$0.39 \mathrm{Nm}^{3} / \mathrm{MJ}$ for MBM), also giving a lower clinker-specific air requirement for coal $\left(0.51 \mathrm{Nm}^{3} / \mathrm{kg}\right.$ of clinker $)$ than for MBM $\left(0.63 \mathrm{Nm}^{3} / \mathrm{kg}\right.$ of clinker $)$, as seen in Fig. 3. Moreover, an increase in the oxygen content in the fuel also gives a reduction in air requirement, and hence an increase in temperature. Many alternative fuels except MBM have higher oxygen content compared coal, meaning that a higher proportion of the total $\mathrm{O}_{2}$ requirement is supplied via the fuel itself in other fuels compared to coal, hence less air is required. However, this is opposite for MBM. The air requirement is a result of all these phenomena. The increase in air requirement will increase the secondary air consumption since the primary air supply is kept constant. The extra secondary air has to be supplied from the cooler by routing some of the low-temperature excess cooling air to the rotary kiln and the calciner. However, this means that the average temperature of the combustion air will be reduced, which in turn means that the fuel rate has to be further increased in order to achieve the required heat transfer to the clinker. I.e. the air requirement is again increased resulting in a still higher exhaust gas flow rate and consequently reduced production capacity.

Basically, the kiln gas flow rate follows the same trend as the air flow rate (Fig. 2). The fact that the kiln gas flow rate is higher than the air flow rate is due to the addition of fuel (which is converted to combustion products) and the addition of $\mathrm{CO}_{2}$ from the rest calcination. The clinker-specific gas flow rate is an important parameter since it impacts the production capacity of the kiln system; in general the higher the clinker-specific gas flow, the lower the production capacity of the kiln system. It appears that MBM is quite different from the other alternative fuels in this respect, giving a much higher kiln gas flow rate. Wood, RDF and SHW all have kiln gas flow rates comparable to that of coal.

In general, the alternative fuels have higher $\mathrm{H}_{2} \mathrm{O}$ percentage in the kiln gas than does coal (not presented graphically). As an example, coal has $4.5 \mathrm{vol} \%$ of $\mathrm{H}_{2} \mathrm{O}$ in the kiln gas and all other alternative fuels show at least 10.0 vol\% for that number. The reason is mainly the higher $\mathrm{H} / \mathrm{C}$ ratio in alternative fuels. The higher moisture content in alternative fuels is another characteristic also giving higher $\mathrm{H}_{2} \mathrm{O}$ content in the kiln gas.

\section{B. Combustion of a Mix of Coal and MBM (Case 2)}

The results obtained from the simulation are compared with the result from a full-scale test [12].

Compared to the reference case (pure coal), the specific fuel consumption in case 2 (step 1) is high since the fuel mix contains MBM having fuel characteristics different from coal, as explained above (Fig. 4). The kiln gas temperature is $56^{\circ} \mathrm{C}$ lower than in the reference case, and the total exhaust gas flow rate at normal conditions is now $5.7 \%$ higher. In step 2, the specific fuel consumption is increased to obtain same kiln gas temperature as in the reference case $\left(1145{ }^{\circ} \mathrm{C}\right)$. The clinker-specific energy consumption in the main burner is increased by $7.9 \%$ in this step. The air requirement for the combustion increases with the increase of fuel consumption, hence the kiln gas flow rate is further increased from 222 to $228 \mathrm{kNm}^{3} / \mathrm{h}$. The clinker-specific air requirement at normal conditions for step 2 is calculated as $0.62 \mathrm{Nm}^{3} / \mathrm{kg}$ of clinker. In step 3, the total exhaust gas flow rate is the same as in the 
reference case $\left(210 \mathrm{kNm}^{3} / \mathrm{h}\right)$, however, the penalty is a reduced clinker production rate; around $9 \%$ reduction in clinker production is calculated. In this case, the raw meal requirement is lower, hence the fuel energy requirement and $\mathrm{CO}_{2}$ release due to calcination is lower in the precalciner, resulting in reduced exhaust gas from the precalciner, compensating for the increased exhaust gas from the kiln. (The sum of the two is equal to the total flow rate in the reference case.) All simulations in case 2 were carried out with $7 \mathrm{t} / \mathrm{h}$ of MBM feeding at the main burner, corresponding to the bottleneck found from the full-scale test [12].

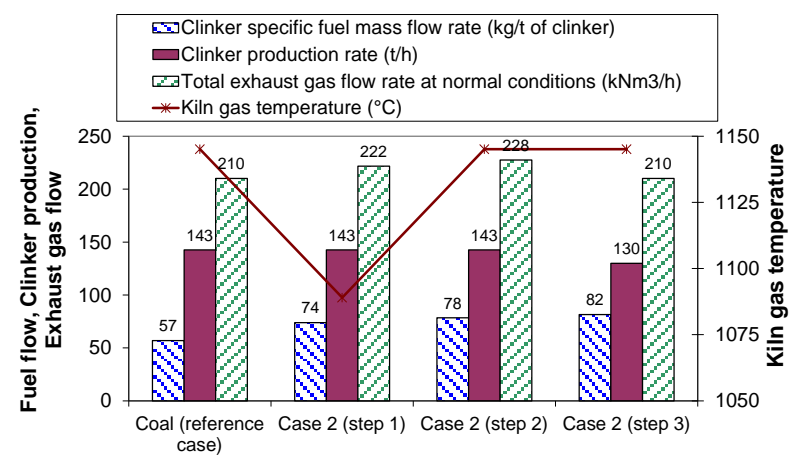

Fig. 4. Fuel flow, clinker production and exhaust gas flow rate for case 2 compared with the coal reference case.

Fig. 5 and Fig. 6 explain some results from the full-scale test. As can be seen in Fig. 5, when the MBM feeding rate was increased to $7 \mathrm{t} / \mathrm{h}$, the free lime (i.e. uncombined $\mathrm{CaO}$ ) content increased above the maximum allowable limit $(2.5 \mathrm{wt} \%)$ for the clinker type produced. Therefore, the raw meal feed rate (determining the clinker production) had to be reduced by $2.3 \%$ in the last hour of the test [12]. However, one hour after the reduction in clinker production, the free lime content was still too high, meaning that the clinker production should have been reduced even more to reduce the free lime to an acceptable level. This fits quite well with the $9 \%$ reduction predicted by the model simulation.

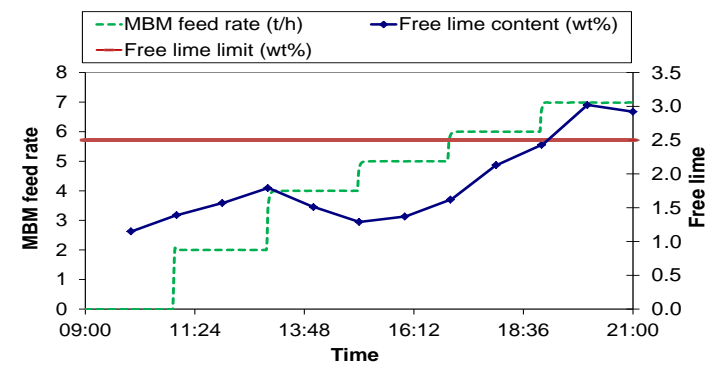

Fig. 5. MBM feed rate, clinker free lime content and limit in clinker from the full-scale test.

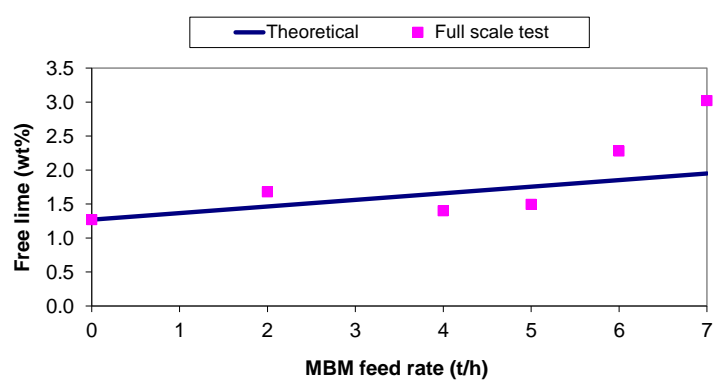

Fig. 6. Resulting free lime in clinker by feeding MBM [12].
Why does the free lime level increase, when the MBM input is increased? As discussed in a previous paper [12], one reason could be the additional Ca added via MBM. Fig. 6 indicates the maximum theoretical free lime content that could be added to the clinker via the MBM feed, conservatively assuming that all the calcium which enters with MBM will end up as free lime.

However, as shown in Fig. 6, this reason cannot entirely explain the measured increase in free lime in the full-scale test. Hence, there must be heat transfer related phenomenon as well contributing to increased free lime in the clinker: Combustion of MBM at high rates may reduce the heat transfer to the clinker due to lower combustion temperature in the rotary kiln. This effect has now been verified and explained through the simulation results. Thus, in a full-scale production situation, one usually has to reduce the production capacity in order to maintain the product quality when large amounts of alternative fuels are utilized.

\section{CONCLUSION}

A mathematical model based on a steady-state mass and energy balance for a cement kiln main burner was developed and used to simulate what happens when coal is replaced by different solid alternative fuels.

Many key process parameters like kiln gas temperature, kiln gas flow rate and air requirement are hugely dependent on the chemical characteristics of the fuel supplied. In general, feeding biogenic or partly biogenic alternative fuels decreases the kiln gas temperature, meaning a reduction in clinker production capacity. However, the air requirement and kiln gas flow rate depend on the chemical composition of fuel, and it appears that MBM is quite different from the other alternative fuels in this respect, having a higher air requirement and kiln gas flow.

From the model simulations it was found that in order to keep the required clinker quality when replacing around 59\% of the coal energy by MBM at the main burner, the production capacity had to be reduced by $9 \%$. This simulation result was verified by a full-scale test applying the same fuel mixture and the same input parameters as used in the model.

\section{REFERENCES}

[1] P. Lemieux, E. Stewart, M. Realff, and J. A. Mulholland, "Emissions study of co-firing waste carpet in a rotary kiln," Journal of Environmental Management, vol. 70, no. 1, pp. 27-33, Jan. 2004.

[2] G. Genon and E. Brizio, "Perspectives and limits for cement kilns as a destination for RDF," Waste Management, vol. 28, no. 11, pp. 2375-2385, Nov. 2008.

[3] K. H. Karstensen, "Formation, release and control of dioxins in cement kilns," Chemosphere, vol. 70, no. 4, pp. 543-560, Jan. 2008.

[4] S. Zemba et al., "Emissions of metals and polychlorinated dibenzo(p)dioxins and furans (PCDD/Fs) from Portland cement manufacturing plants: Inter-kiln variability and dependence on fuel-types," Science of the Total Environment, vol. 409, no. 20, pp. 4198-4205, Sep. 2011.

[5] U. Kaantee, R. Zevenhoven, R. Backman, and M. Hupa, "Cement manufacturing using alternative fuels and the advantages of process modelling," Fuel Processing Technology, vol. 85, no. 4, pp. 293-301, Mar. 2004.

[6] U. Kääntee, R. Zevenhoven, R. Backman and M. Hupa, "Modelling a cement manufacturing process to study possible impacts of alternative fuels," in Proc. Extraction and Processing Division Meeting on 
Recycling and Waste Treatment in Mineral and Metal Processing: Technical and Economic Aspects, Sweden, June 16-20, 2002.

[7] I. K. Kookos, Y. Pontikes, G. N. Angelopoulos, and G. Lyberatos, "Classical and alternative fuel mix optimization in cement production using mathematical programming," Fuel, vol. 90, no. 3, pp. 1277-1284, Mar. 2011.

[8] C. A. Tsiliyannis, "Alternative fuels in cement manufacturing: Modeling for process optimization under direct and compound operation," Fuel, vol. 99, pp. 20-39. Sep. 2012.

[9] D. C. Nastac, U. Kaantee, J. Liimatainen, M. Hupa, and M. Muntean, "Influence of $\mathrm{P}(\mathrm{V})$ on the characteristics of calcium silicates and the hydration of clinkers," Advances in Cement Research, vol. 19, no. 3 pp. 93-100, July 2007.

[10] E. Cascarosa, G. Gea, and J. Arauzo, "Thermochemical processing of meat and bone meal: A review," Renewable and Sustainable Energy Reviews, vol. 16, no.1, pp. 942-957, Jan. 2012.

[11] I. Vermeulen, J. V. Caneghem, C. Block, W. Dewulf, and C. Vandecasteele, "Environmental Impact of Incineration of Calorific Industrial Waste: Rotary Kiln vs. Cement Kiln," Waste Management, vol. 32, no. 10, pp. 1853-1863, Oct. 2012.

[12] W. K. H. Ariyaratne, M. C. Melaaen, K. Eine, and L. A. Tokheim, "Meat and Bone Meal as a Renewable Energy Source in Cement Kilns: Investigation of Optimum Feeding Rate," presented at the International Conference on Renewable Energies and Power Quality, Spain, Apr. $13-15,2010$.

[13] L. A. Tokheim, "Kiln system modification for increased utilization of alternative fuels at Norcem Brevik," Cement International, vol. 4, pp. $52-59,2006$

[14] W. K. H. Ariyaratne, Ø. Asgautsen, M. C. Melaaen, K. Eine, and L. A. Tokheim, "Determination of fossil fraction of Refuse Derived Fuel by the Selective Dissolution Method in Calorific value basis Development of simplified method," Fuel, vol. 98, pp. 41-47, Aug. 2012.

[15] Execution and Evaluation of Kiln Performance Tests, Specification Vt10: Report, German Association of Cement Works (VDZ) -1992.

[16] L. A. Tokheim, "The impact of staged combustion on the operation of a precalciner cement kiln," Ph.D. dissertation, Telemark University College / Norwegian University of Technology and Science, Norway, 1999.

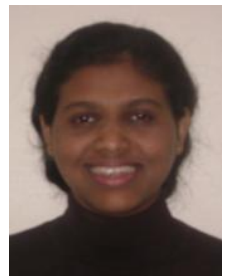

W. K. Hiromi Ariyaratne has one MSc degree in process technology from Telemark University College (TUC), Porsgrunn, Norway in 2009 and another MSc degree in chemical and process engineering from University of Moratuwa (UOM), Moratuwa, Sri Lanka in 2007 and a BSc degree in chemical and process engineering from UOM, 2004.

She is a PhD Student at TUC since 2009, where her topic is related to alternative fuel combustion in cement kilns. She has worked on research projects as a research fellow in Sevanagala Sugar Industries (Pvt) Ltd, Sri Lanka and Research and Development Institute, Sri Lanka (2006-2007). She has work experience as a chemical and process engineer in Hammer International (Pvt) Ltd, Sri Lanka (2006) and Linea Intimo (Pvt) Ltd, Sri Lanka (2003). She has also worked at Department of Chemical and Process Engineering at UOM as Teaching Assistant (2005).

Mrs. Ariyaratne's research interests are alternative fuel combustion in cement clinker production, modeling and simulation, fluid dynamics, heat and mass transfer and cleaner production and waste management techniques.

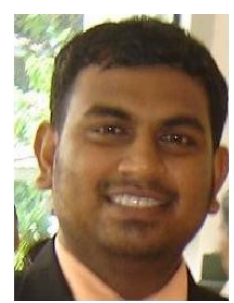

E. V. P. J. Manjula has MSc degree in systems and control engineering from Telemark University College (TUC), Porsgrunn, Norway in 2011 and a BSc degree in electrical and electronic engineering from University of Peradeniya, Kandy, Sri Lanka in 2003.

$\mathrm{He}$ is a temporary teaching assistant for the master level academic module called "modeling and simulation of dynamic systems" at TUC. He has industrial experience from Ceylon Electricity Board, Sri Lanka since 2005: as an area electrical engineer, maintenance engineer, operational electrical engineer and system control engineer. He has also worked as a summer student at Telemark Technological Research and Development Center (Tel-Tek), Porsgrunn, Norway in 2010.

Mr. Manjula's research interests are modeling and simulation, hydro power and automation.

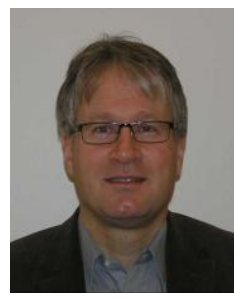

Morten C. Melaaen received his MSc degree in mechanical engineering in 1986 and his $\mathrm{PhD}$ in 1990 both from Norwegian University of Science and Technology from NTNU, Trondheim, Norway.

$\mathrm{He}$ is a professor in process technology at Telemark University College, Porsgrunn, Norway. He is also the Dean of Faculty of Technology, Telemark University College and has a part time position at the local research institute Tel-Tek. Earlier, he has worked as a Research Engineer in Division of Applied Thermodynamics, SINTEF, Norway and as an Associate Professor at NTNU. He has worked on research projects as a Senior Research Scientist in Norsk Hydro Research Centre Porsgrunn, Norway. He started to work as a professor at Telemark University College in 1994 and became Head of Department, Department of Process, Energy and Environmental Technology in 2002. Prof. Melaaen's research interests are $\mathrm{CO}_{2}$ capture, modeling and simulation, fluid mechanics and heat and mass transfer. Prof. Melaaen has more than 110 scientific papers published in the above mentioned related fields in international journals and conferences.

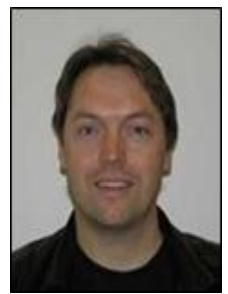

Lars-André Tokheim has a $\mathrm{PhD}$ degree in combustion from Telemark University College (TUC), Porsgrunn, Norway in 1999 an MSc degree in industrial environmental technology from TUC, 1994 and a BSc degree in chemistry from TUC in 1992.

$\mathrm{He}$ is an associate professor at TUC since 2006, where he teaches gas purification and heat \& mass transfer, supervises MSc and $\mathrm{PhD}$ students, and coordinates master study programmes in process technology and energy \& environmental technology as well as a PhD study programme in process, energy \& automation engineering. He has industria experience from Norcem/Heidelberg Cement since 1994: as a Research Scholar (1994-1998), as a process engineer in the production department (1998-2001), and as head of Department for Process Development and Environment (2001-2006)

Prof. Tokheim's main research interests include use of alternative fuels in cement clinker production, calciner technology and gas pollution reduction, in particular $\mathrm{CO}_{2}$ capture and $\mathrm{NO}_{x}$ reduction 